\title{
Realization of wheat (Triticum aestivum L.) productivity, profitability and nutrient balance sheet through improved nutrient management
}

\author{
VIPIN KUMAR, SANDEEP KUMAR*, OMBIR SINGH AND AVESH KUMAR \\ Department of Agronomy, Chaudhary Chhotu Ram Post-Graduate College, MUZAFFARNAGAR (U.P.) INDIA \\ Email: sandeepkail@yahoo.com
}

\begin{abstract}
A field experiment was conducted during Rabi seasons of 2007-08 and 2008-09 to study the realization of wheat (Triticum aestivum L.) productivity, profitability and nutrient balance sheet through improved nutrient management. Sixteen fertility treatment combinations of $\mathrm{NPK}$ and $\mathrm{ZnSO}_{4}$ were examined in Randomized Block Design with three replications. Application of $\mathrm{NPKZnSO}_{4} @ 150: 75: 60: 20 \mathrm{~kg} / \mathrm{ha}$ produced highest grain yield of $51.0 \mathrm{q} / \mathrm{ha}$ being significantly higher by 71.7, 57.9, 42.5, 49.9 and 9.5 per cent over control, NPK ZnSO ${ }_{4}$ levels of $90: 45: 45: 00,90: 45: 45: 20,90: 45: 45: 40$ and $120: 60: 45: 00 \mathrm{~kg} / \mathrm{ha}$, respectively. Further, increase in fertility levels beyond 150:75:60:20 kg NPK ZnSO $/$ /ha did not show any significant improvement in grain yield. However, the yield attributes viz., spikes $/ \mathrm{m}^{2}$, grains/spike, test weight and spike fertility ratio increased significantly upto $120: 60: 45: 20 \mathrm{~kg} \mathrm{NPK} \mathrm{ZnSO}_{4} /$ ha over control, $90: 45: 45$, (with and with out $\mathrm{ZnSO}_{4}$ ) and $120: 60: 45 \mathrm{~kg} \mathrm{NPK} /$ ha but remained at a par with other levels of fertility tested in the experimentation. Most of the growth and developmental parameters in the study significantly increased upto the highest level of fertility management i.e. $150: 75: 75: 40 \mathrm{~kg} / \mathrm{ha}$. Comparison of available NPK and $\mathrm{Zn}$ in soil after harvest of crop with the initial status under different treatments indicated the reduction in residual soil available nutrients at their lower level of application. However, an increase in available NPK in soil were noticed with the application of 150 $: 75: 60$ and $150: 75: 75 \mathrm{~kg} \mathrm{NPK} / \mathrm{ha}$ with and without $\mathrm{Zn}$ level, while the status of $\mathrm{Zn}$ in soil was found positive with other primary nutrient under treatment $150: 75: 75: 20$ and $150: 75: 75: 40 \mathrm{~kg} \mathrm{NPK} \mathrm{ZnSO}_{4} /$ ha only. Wheat crop grown under the fertility treatment $150: 75: 60: 20 \mathrm{~kg} \mathrm{NPK} \mathrm{ZnSO}_{4}$ /ha recorded maximum net monetary return of Rs. 36,331/ha which was on an average just the double of all those treatments where nitrogen was applied @ $90 \mathrm{~kg} / \mathrm{ha}$.
\end{abstract}

Key Words : Balance sheet, Growth, N P K Zn uptake, Productivity, Profitability, Wheat

View Point Article : Kumar, Vipin, Kumar, Sandeep, Singh, Ombir and Kumar, Avesh (2017). Realization of wheat (Triticum aestivum L.) productivity, profitability and nutrient balance sheet through improved nutrient management. Internat. J. agric. Sci., 13 (2) : 222-227, DOI:10.15740/HAS/IJAS/13.2/222-227.

Article History : Received : 23.01.2017; Revised : 08.04.2017; Accepted : 22.04.2017

\footnotetext{
* Author for correspondence:
} 